\title{
Strategies for Maritime Development: A Case in Vietnam
}

\author{
Xuan Phuong Nguyen, and Phuoc Quy Phong Nguyen
}

\begin{abstract}
Strategic assessors of the 21st century are "The Century of the Ocean," because, along with current economic and demographic growth, natural resources, especially nonrenewable resources on land, will be exhausted after several decades. The world economy is increasingly dependent on the sea and the ocean. About $70 \%$ of the world's industrial potential is in the $500 \mathrm{~km}$ wide area of the coast. The mineral, biological and marine resources of the oceans and oceans have an important implication for the world economy. Marine ecosystems are the most important resource with hundreds of thousands of animals, plants, and microorganisms. Sea is a diversified and abundant source of seafood, chemicals, salt, oil and gas, clean energy from the sea and oceans, wind, seawater, ocean currents, and the tide is being exploited for transportation, energy and countless other human benefits. The sea and the continental shelf are waterways that can develop tourism, sightseeing and recreation activities. The role of marine economics, including maritime economics, has become increasingly important and has been identified as a key sector for investment. This paper analyzes the advantages, limitations, and causes in maritime economic development, and draws on experiences to develop the maritime economy.
\end{abstract}

Index Terms-Energy; Development Strategy; Vietnam Maritime; Port; Ship Fleet.

\section{INTRODUCTION}

The development history of the world shows that the breakthroughs of world-class development have so far come from the nations of the sea such as the United States, Japan, China, and Singapore. They do not own abundant natural resources but have a very developed marine economy thanks to its geographic location. US seaports annually earn hundreds of billions of dollars from passenger and freight services and create millions of jobs for workers. Meanwhile, the world's second-largest economy, China says the size of its maritime economy is growing rapidly, projected to contribute 10 percent of GDP in 2015 and double that of 2020 with 3.840 billion yuan in 2010 . It is noteworthy that ocean technology could account for more than $60 \%$ of the GDP of the Chinese maritime economy in 2015 [1]. Particularly for Russia, the sea plays an extremely important role with the length of tens of thousands of kilometers with great mineral potential. With reserves of about 13.7 billion tons of oil and 52.3 trillion cubic feet of gas, Russia has an abundant source of budget revenue for the socio-economic development and consolidation of its position in the international arena. Earlier, European marine economic ministers called for greater use of the opportunities of European seas as a way for Europe's leading states to break out of the economic crisis [2].

Published on December 5, 2018.

X. P. Nguyen and P. Q. P. Nguyen are with Ho Chi Minh city University of Transport, Ho Chi Minh city, Vietnam.
Vietnam has a coastline of more than $3,260 \mathrm{~km}$ and is located on the arterial shipping route with a very high flow of ships around the world, which has great potential for marine economic development. In fact, in the past few years, the maritime sector has made important contributions to the socio-economic development of the country. Therefore, the protection of the marine environment will be a prerequisite for the sustainable development of the marine economy [3]. Up to now, Vietnam's seaport system is quite complete from the North to the South with 45 seaports, including 256 ports/402 wharves with a total designed capacity of 470 - 500 million tons of cargo per year, receiving over 120 thousand ship turns per year. With the motto of developing Vietnam's maritime industry, integrating into the international economy and protecting the environment towards sustainable development. Accordingly, with the provisions of the UN Convention on the Law of the Sea (UNCLOS 1982) and other relevant conventions to which Vietnam is a member, the maritime industry has implemented synchronously and appropriately. Content and orientation of development planning of Vietnam seaport system, Vietnam's sea transport development plan for the development of Vietnam's shipbuilding industry up to 2020 with an orientation to 2030. However, in order to better realize the marine environment protection in the coming time, the Vietnam Maritime Bureau's director said that it is necessary to complete the system of domestic legal documents on pollution prevention from the environment caused by the ship in shipping activities to fully and comprehensively implement the legal documents, MARPOL Convention provisions [4]. At the same time, it is necessary to establish and implement a proper ship control and monitoring process to assist in the prompt and accurate investigation of marine accidents related to pollution incidents [5]. Another task that the maritime sector has mentioned is the propagation and dissemination of the contents of the MARPOL Convention and the appendices of the Convention to organizations and individuals operating in the maritime field and vessels operating in seaports in Vietnam [6],[7]. Research and application of equipment for inspection, control, and treatment of wastes arising from ships, the implementation of the provisions of the MARPOL Convention and the annexes of the Convention are the legal basis for conducting state inspection at seaports, organizing the supervision, investigation, and handling of violations of environmental protection of seagoing vessels, creating favorable conditions for Vietnamese ships, maritime activities in the country and internationally, contributing to the socio-economic development of the country [8]. This is in line with the general trend of the world's maritime industry, the international economic integration process, and the strengthening of Vietnam's position in maritime transport. 


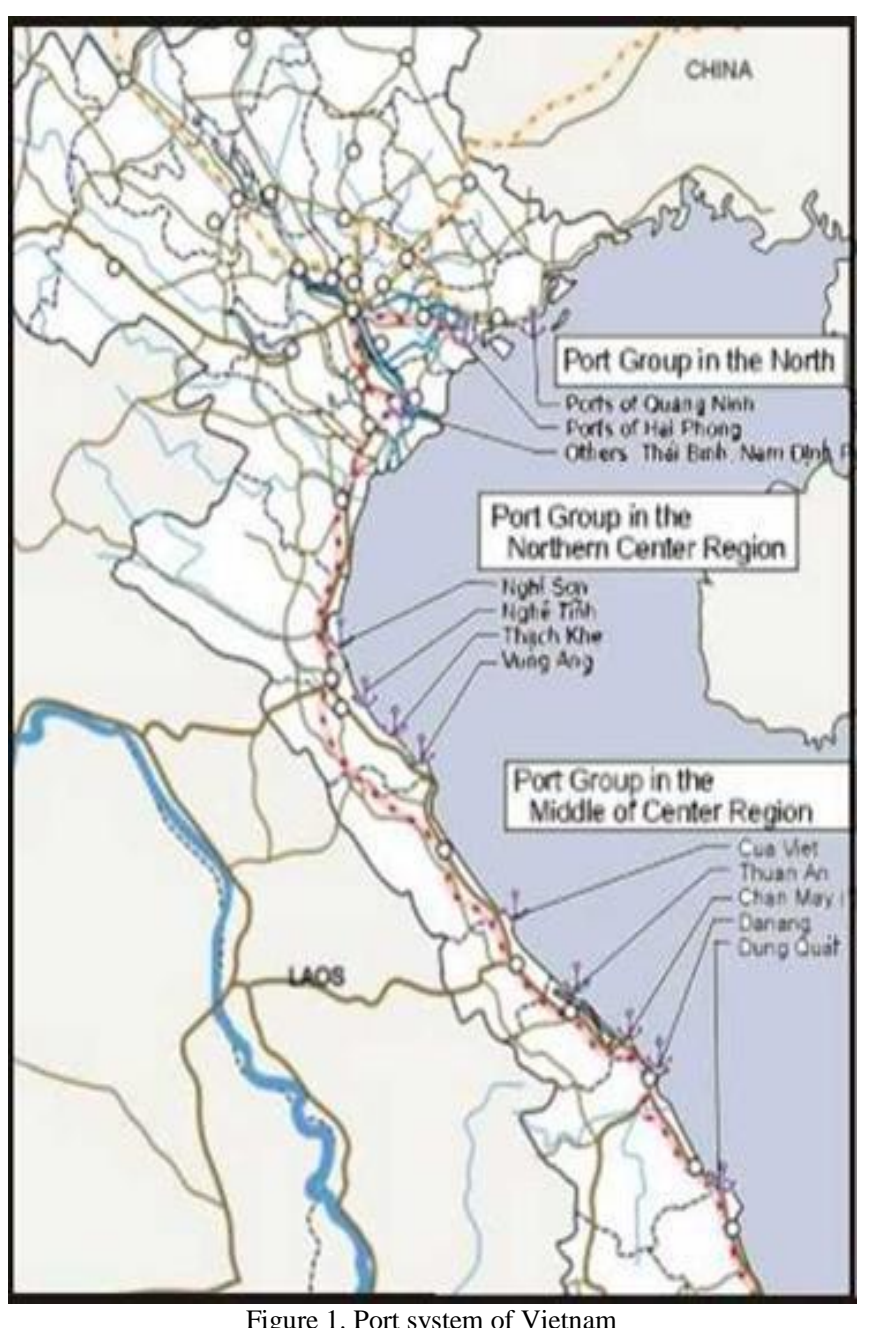

In the first months of 2017, the world economic situation changed positively with positive growth momentum, and global trade and investment recovery was a positive factor for domestic production. Besides the outstanding results in improving the business environment, business development, our country's economy is also facing difficulties, the growth rate has signs of slowing down. These common advantages and disadvantages have affected the operation of enterprises and management agencies in the maritime field, especially for maritime transport [9]. The number of container ships carrying the Vietnamese national flag has increased to 33 vessels (from 19 vessels in 2013). Vessels carrying the flag of Vietnam basically took up nearly $100 \%$ of domestic shipments, except for some specialized ships such as LPG and cement. In the first six months, by the Vietnamese fleet is estimated at 88.5 million tons, up $3 \%$ over the same period in 2016. At the same time, the output of goods through the port system of Vietnam estimated at 254.5 million tons, up $11 \%$ over the same period, reaching $51 \%$ of the plan, of which containerized 6.87 million TEUs, up 5\% over the same period in 2016, reaching $46 \%$ of the plan in 2017 [1]. The port of VR-SB was estimated at 8.1 million tons, an increase of $62 \%$ over the same period last year with more than 10 thousand ships. However, the business situation of the shipping companies in Vietnam continues to face many difficulties due to excess supply of ships, low volume of cargoes, and reduced freight rates. Many shipping companies, including large ones, continue to suffer losses.
The scope of operations of Vietnam's shipping fleet is mainly on short-haul routes of Southeast Asia and Northeast Asia, which accounts for only about $10 \%$ of Vietnam's export and import market, but poor linkage between shipowners and shipowners with cargo owners [10]. In the first six months of the year, besides favorable factors such as stable macroeconomic situation, the port entry and cargo production through seaports grew well while measures to strengthen the inspection. As a result, port fees were VND 396.16 billion, up 4\% over the same period 2016 and exceeded $4 \%$ of the estimated delivery; maritime security fees reached 758.33 billion, up 3\% over the same period in 2016 and exceed 3\% compared with the estimated delivery; Leasing of port facilities and wharf reached VND 76.32 billion, up 55\% over the same period of 2016 and exceeded $11 \%$ of the estimated delivery; The total amount paid to the state budget was VND 996.42 billion, surpassing $02 \%$ of the estimated budget. This result was due to the increase in cargo throughput of seaports, the revenue and profits of the rented enterprises. The infrastructure of the harbor, wharf is growing well.

\section{CHARACTERISTICS OF VIETNAMESE MARITIME}

The maritime industry has a great impact on the economy in general and is particularly related to the marine economy, tourism and commerce. However, Vietnam's shipping industry is facing many challenges in terms of technology, operational efficiency, access to capital as well as capacity to meet transport demand from new markets. Data $\mathrm{n}$ loaded 130.9 million tons and took over $100 \%$ domestic container shipping by sea. As of May 20, 1974, the fleet of Vietnam has owned 1,406 cargo ships [11].

Vietnam's maritime industry is leaving the domestic market, especially not taking advantage of the national advantages. Vietnam has a long coastline, great tourism potential, but so far almost no business interest, completely let people develop spontaneously. Vietnam has no tourist fleet of any size, including river and sea, which leads to 99.9\% of Vietnamese have not been traveling along the country by sea. If we want to develop the maritime industry in Vietnam, we should start with ideas that do not need to be super high for the purpose of serving the people in the country has too much potential in tourism as well as fishing. The difficulty of the maritime industry has been going on for a long time and its remnants are still present. In spite of this, in 2017, the picture of the global economy was assessed simultaneously with the prosperity, in which the volume of sea transport of the Vietnamese fleet in this year also grew sharply, approximately 7\% compared to 2016. This is a sign of recovery and prosperity in maritime activities this year and next. Vinalines currently owns over 90 vessels with a combined tonnage of 2 million tons and a system of 14 major ports and deepwater ports nationwide. Along with that, the integrated logistic system transports more than 20 percent of the nation's transport capacity by 2017 [12].

In addition to finding partners, Vietnamese businesses are looking for strategic investors. In particular, with Vinalines in 2018 will proceed to equitization, moving from a $100 \%$ state-owned company model to a joint-stock model, 
therefore, seeking strategic investors to be able to divide The same company in operation, technical cooperation and market expansion and management will be extremely necessary for the present time [13]. With new technologies applied in the maritime industry and the presence of national and international experts, Vietnam's maritime industry can take advantage of opportunities to grow and be more competitive in the region as well as the world. APM 2018 will help introduce the prospects of the maritime sector in Vietnam with new global business opportunities. As a result, businesses have the ability to approach maritime and offshore industry professionals from international trading properties, understand more about the position and future direction of the Vietnamese and European maritime industries, thereby seeking strategies, opportunities to develop as well as make full use of ASEAN's comprehensive capabilities [14].

In the past few years, the maritime industry has not really prospered but now there are signs of recovery. As people working in this field, we have the basis to believe that if the opportunity is well caught, the maritime industry can catch up with the trend to develop and improve the capacity of the Vietnamese maritime industry as well as international integration.

\section{StRATEgIES FOR MARITIME DEVELOPMENT}

In the strategy of marine economic development, the maritime sector plays an important role, in which seaports are the nucleus of development, the focal point for receiving and transporting import and export goods and circulating to all regions of the country. Shipping now accounts for $90 \%$ of the volume of imports and exports and part of the goods to regions, the main artery in the system of transportation and distribution of goods of the economy [15]. To determine the importance and necessity of researching and developing the sea development strategy to take advantage of and exploit the sea potential to serve the development of the country.

\section{A. Building and improvement of the system of maritime law and join international treaties}

Maritime is highly internationalized, with many complex activities involving people, boats, seaports, goods, environment both in the country and internationally. Marine disputes often involve many countries and territories. This requires that each country's maritime legal system be built in a way that ensures that all activities in the maritime field are regulated and that it conforms to the provisions of the international practice. In order to meet that requirement and serve the marine economic development, the system of legal documents on maritime law of Vietnam has been paid attention, research, amendment, and supplement in time. The Maritime Ministry has completed the study and proposal of the Ministry of Communications and Transport, the Government and the National Assembly to amend the Maritime Code of Vietnam with amendments and supplements in line with the actual operation of the maritime service and the treaty, international practice, passed by the National Assembly in 2015; To elaborate and submit to competent authorities for promulgation the Government's decrees, decisions of the Prime Minister and circulars of the minister in detail guiding the implementation of the Maritime Code of Vietnam. On the other hand, in order to support the development and integration of the world, the maritime sector has consulted and recommended to the Government to accede 26 conventions, international agreements, and protocols, signing 26 agreements bilateral and 27 agreements on the recognition of professional certificates with countries in the region and the world; Members of international organizations of international importance such as the International Maritime Organization (IMO), the International Labor Organization (ILO), the Association for the Advancement of Women International Maritime and Lighthouse Administration (IALA), International Maritime Organization (INMARSAT). Strategic planning, planning and policy development of the maritime industry [16].

\section{B. Building strategies, planning, and policies for the development of the maritime industry}

In order to ensure the development of the maritime economy, a component of maritime economic development, the development of strategies, planning and development policy for the sector in each period plays a very important role and is Sector leaders pay attention. Up to now, the marine industry has developed and approved by the competent authorities the master plans, policies, and projects such as:

Planning on the development of Vietnam's seaport system up to 2020 and orientations to 2030, comprising 6 seaport groups with the objective of ensuring through the whole volume of import and export goods and exchanges between regions and regions in the country. By sea, meeting the requirements of socio-economic development of the country with the capacity adopted in accordance with the planning of the seaport system at specific times: reaching 640 to 680 million tons/year (of which Synthetic cargoes, containers of between 375 and 400 million tons/year) by 2020; reaching from 1,040 to 1,160 million tons / year (of which synthetic goods, containers of 630 to 715 million tons / year) by 2030; To concentrate on building international gateway ports in Hai Phong, Ba Ria-Vung Tau and the key economic region of the Central Vietnam, capable of receiving ships of up to 100,000 DWT, container ships of up to 8,000 TEU or larger; have the capacity to integrate the role of international container transshipment; To build large-scale specialized ports for metallurgical complexes [17]-[23], petrochemical refineries, coal-fired thermal power plants [14].

Planning on the development of Vietnam sea transport up to 2020 , with orientation to 2030 with the following principal contents: To develop modern ocean shipping with higher and higher quality, minimizing environmental pollution [24]-[30] and saving energy and using the alternative fuel [31]-[42]; To increase the competitiveness to actively integrate and expand the shipping market in the region and the world; in line with the development of modes of road transport, inland waterways, railways and airways; Application of modern and advanced transport technology [43],[44]; To attach importance to the development of multimodal transportation and logistic services in order to create a synchronous and efficient transport system; To improve 
the quality of sea transport services in order to handle domestic cargoes, to reduce the load for transportation by road; undertake to transport most of the volume of goods exported or imported by sea; To meet the demand of sea transportation of the economy with high quality, reasonable price and minimize environmental pollution.

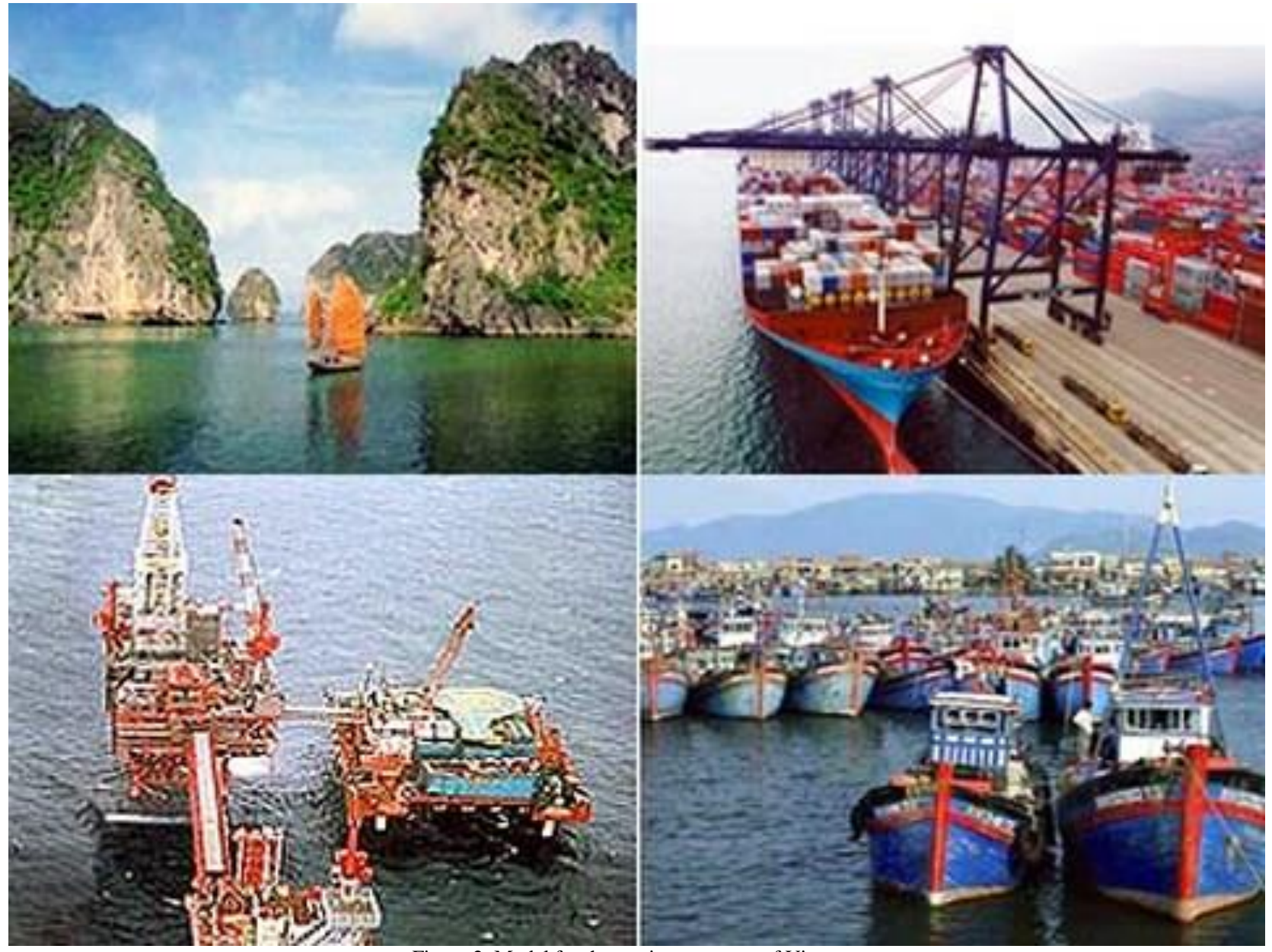

Figure 2. Model for the marine economy of Vietnam

Develop the maritime traffic along the direction of modernity, sustainability, and efficiency, linking with environmental protection, bringing into full play potential and strengths of the country;

Develop the maritime transport market, ensuring the capability to support the road, rail, and air transport; To raise the quality of services and reduce transport costs, to meet in time and fully meet the demand for goods and passenger transportation, thus contributing to raising the competitiveness of the economy;

Build a synchronous and modern navigation system on the basis of using rational resources for investment, prioritizing international transshipment projects, spilloversensitive and preservation works. to connect modes of transport, major economic centers; strengthen the maintenance of existing facilities to improve capacity through;

Improve efficiency, business and production capacity and competitiveness of maritime businesses by strengthening the development of enterprises that hold key stages and lifeline;

Strengthen the role of state management, reforming policy institutions, creating a transparent and open legal framework, reforming administrative procedures along the direction of simplifying, facilitating, removing difficulties, To create incentives for all economic sectors to invest in the development of maritime transport infrastructure;
Apply modern technologies in the development, construction, and management of the maritime industry; training and developing high-quality human resources. In order to attach importance to raising the capability of making policies and forecasting, organizing the management of investment in development, management and exploitation of maritime infrastructure and management of sea transport.

C. Reforming of administrative procedures and application of science and technology in the management of the maritime state

The reform of administrative procedures and the application of science and technology in the state management of maritime specialties is necessary to simplify procedures and create favorable conditions for people and businesses operating in the field to reduce production and business costs. In line with that requirement, the maritime sector reviewed, cut, developed and published 107 administrative procedures in the maritime field, of which 57 administrative procedures were provided online level $2 ; 35$ administrative procedures provided online level 3 and 15 administrative procedures provided online level 4 Authorization and decentralization of administrative procedures were also carried out thoroughly [45]. The Vietnam Maritime Bureau has delegated authority from the head of the Department to the heads of the advisory sections 
and decentralization from the Department to the port departments and porters to carry out administrative procedures and create favorable conditions for them for the people in carrying out the procedures for granting professional capacity certificates and crew members' passports.

\section{Ensuring maritime safety, maritime security, freedom of navigation and sovereignty of Vietnam at sea}

This secure transmission and transmission has been very effective in limiting accidents at sea, helping ships to recognize weather abnormalities early in order to take timely preventive measures and especially useful in the search and rescue of victims at sea.

Maritime and navigational signaling systems: Maritime and navigational signaling systems are always ensured technical specifications for announcing and maintaining the operation of marine lights, signboards, and marine signaling buoys [46].

VTS, AIS and LRIT systems: The introduction of the VTS system in the exploitation and use has contributed to improving the efficiency of the management, monitoring and regulating the operation of means in the port waters. In addition, LRIT, the AIS system has been established and operated, contributing to the monitoring of all ships operating in Vietnamese waters and Vietnamese vessels operating all around the world.

Organizing the search and rescue at sea: The Vietnam Maritime Search and Rescue Coordination Center is a marine navigation search and rescue force, performing search and rescue obligations in Vietnam's sea areas strictly according to Obligations of States Parties to the International Convention for the Search and Rescue of SARs 79.

Maintaining and developing the above mentioned systems and services have positively contributed to ensuring the safety of the operation of vessels at sea, the freedom to navigate the sea in the East Sea; Well perform the search and rescue obligations of the coastal state and contribute to protecting Vietnam's sovereignty, sovereignty and jurisdiction over the sea.

\section{CONCLUSION}

In the strategy of marine economic development, the maritime sector plays a very important role as the main artery in the domestic and international cargo circulation system and at the same time is the nucleus for socioeconomic development. It is a gateway to trade, cultural exchange with other countries and a basis for promoting marine economic development. Deeply aware of its role and responsibility, the maritime industry has been determined to build and develop, support the maximum contribution to the successful implementation of the objectives of the strategy of developing Vietnam marine economy on the way of integration with the outside world. Vietnam needs to study and provide a way to cooperate effectively with the country to serve the exploitation of marine potential, development economy and protection of the country. From the lessons and experience of marine economic development in some countries, in order to develop the marine economy sustainably, raising awareness of the whole society on marine economic development strategy is very practical. Formulating a scheme on restructure the marine economic sector, mechanisms and policies to promote the active right of branches; Development of adaptation strategies for coastal livelihoods and ecological environment protection; Increase investment in new construction and consolidation of solid sea dykes; consolidate the information and communication system; Efforts to withdraw the training and fostering of researchers in management of marine economic sectors and coastal communities not only have professional qualifications but also skills in responding to climate change and protecting the sovereignty of the sea and island are considered the necessary works.

\section{REFERENCES}

[1] "http://www.tapchigiaothong.vn/nganh-hang-hai-tap-trung-doi-moico-che-de-phat-trien-d46521.html."

[2] V. V Thai, "Impacts of security improvements on service quality in maritime transport: An empirical study of Vietnam," Marit. Econ. Logist., vol. 9, no. 4, pp. 335-356, 2007.

[3] L. C. Nguyen and T. Notteboom, "Dry ports as extensions of maritime deep-sea ports: a case study of Vietnam," J. Int. Logist. Trade, vol. 14, no. 1, pp. 65-88, 2016.

[4] F. Tarp, D. Roland-Holst, and J. Rand, "Economic structure and development in an emergent Asian economy: evidence from a social accounting matrix for Vietnam," J. Asian Econ., vol. 13, no. 6, pp. 847-871, 2003.

[5] T. A. Hoang, N. X. Chu, and T. Van Tran, "The Environmental Pollution In Vietnam: Source, Impact And Remedies," Int. J. Sci. Technol. Res., vol. 6, no. 2, pp. 249-253, 2017.

[6] V. V. Le and A. T. Hoang, "Fuel and alternative fuel for marine diesel engines," Int. J. Recent Eng. Res. Dev., vol. 2, no. 7, pp. 142-146, 2017.

[7] V. V. Le and A. T. Hoang, "Marine pollution and remedies of Vietnamese Government," Int. J. Recent Eng. Res. Dev., vol. 2, no. 4, pp. 51-55, 2017.

[8] K. R. Hall, A history of early Southeast Asia: Maritime trade and societal development, 100-1500. Rowman \& Littlefield Publishers, 2010.

[9] M. Dell, N. Lane, and P. Querubin, "State capacity, local governance, and economic development in vietnam," NBER Work. Pap., pp. 1-40, 2015.

[10] E. Malesky and J. London, "The political economy of development in China and Vietnam," Annu. Rev. Polit. Sci., vol. 17, pp. 395-419, 2014.

[11] "https://www.vietnamplus.vn/phat-trien-kinh-te-bien-be-phong-chomoi-nen-kinh-te/312164.vnp."

[12] "http://www.tapchicongsan.org.vn/Home/kinh-te/2018/51219/Phattrien-kinh-te-bien-Viet-Nam-Can-phat-huy-tiem-nang.aspx." .

[13] T. V. T. Ho, S. Woodley, A. Cottrell, and P. Valentine, "A multilevel analytical framework for more-effective governance in human-natural systems: A case study of marine protected areas in Vietnam," Ocean Coast. Manag., vol. 90, pp. 11-19, 2014.

[14] "http://tapchitaichinh.vn/nghien-cuu--trao-doi/trao-doi-binhluan/phat-trien-kinh-te-bien-o-mot-so-nuoc-va-bai-hoc-cho-viet-nam80510.html.",

[15] J. Thoburn, "Vietnam as a role model for development," Achiev. Dev. success Strateg. lessons from Dev. world, pp. 99-118, 2013.

[16] "https://infonet.vn/nhung-thach-thuc-doi-voi-kinh-te-bien-viet-namla-gi-post154956.info.”.

[17] X. D. Pham, A. T. Hoang, D. N. Nguyen, and V. V Le, "Effect of Factors on the Hydrogen Composition in the Carburizing Process," Int. J. Appl. Eng. Res., vol. 12, no. 19, pp. 8238-8244, 2017.

[18] T. N. Le, M. K. Pham, A. T. Hoang, and D. N. Nguyen, "Microstructures and elements distribution in the transition zone of carbon steel and stainless steel welds," J. Mech. Eng. Res. Dev., vol. 41, no. 3, pp. 27-31, 2018.

[19] X. D. Pham, A. T. Hoang, and D. N. Nguyen, "A Study on the Effect of the Change of Tempering Temperature on the Microstructure Transformation of Cu-Ni-Sn Alloy," Int. J. Mech. Mechatronics Eng., vol. 18, no. 4, pp. 27-34, 2018.

[20] D. N. Nguyen, A. T. Hoang, M. T. Sai, M. Q. Chau, and V. V. Pham, 
"Effect of Sn component on properties and microstructure $\mathrm{Cu}-\mathrm{Ni}-\mathrm{Sn}$ alloys," J. Teknol., vol. 80, no. 6, pp. 43-51, 2018.

[21] A. T. Hoang, L. H. Nguyen, and D. N. Nguyen, "A Study of Mechanical Properties and Conductivity Capability of CU-9NI-3SN ALLOY," Int. J. Appl. Eng. Res., vol. 13, no. 7, pp. 5120-5126, 2018.

[22] M. K. Pham, D. N. Nguyen, and A. T. Hoang, "Influence of Vanadium Content on the Microstructure and Mechanical Properties of High-Manganese Steel," Int. J. Mech. Mechatronics Eng., vol. 18 no. 2, pp. 141-147, 2018 .

[23] T. N. Le, M. K. Pham, A. T. Hoang, T. N. M. Bui, and D. N. Nguyen, "Microstructure Change For Multi-Pass Welding Between Austenitic Stainless Steel And Carbon Steel," J. Mech. Eng. Res. Dev., vol. 41, no. 2, pp. 97-102, 2018.

[24] A. T. Hoang and X. D. Pham, "An investigation of remediation and recovery of oil spill and toxic heavy metal from maritime pollution by a new absorbent material," J. Mar. Eng. Technol., 2018. https://doi.org/10.1080/20464177.2018.1544401.

[25] A. T. Hoang, "A report of the oil spill recovery and treatment technologies to reduce the marine environment pollution," Int. J. e Navigation Marit. Econ., vol. 9, pp. 35-49, 2018.

[26] A. T. Hoang, V. V Pham, and D. N. Nguyen, "A report of oil spill recovery technologies," Int. J. Appl. Eng. Res., vol. 13, no. 7, pp. 4915-4928, 2018.

[27] P. H. Hoang, A. T. Hoang, N. H. Chung, L. Q. Dien, X. P. Nguyen, and X. D. Pham, "The efficient lignocellulose-based sorbent for oil spill treatment from polyurethane and agricultural residue of Vietnam," Energy Sources, Part A Recover. Util. Environ. Eff., vol. 40, no. 3, pp. 312-319, 2018.

[28] A. T. Hoang, X. L. Bui, and X. D. Pham, "A novel investigation of oil and heavy metal adsorption capacity from as-fabricated adsorbent based on agricultural by-product and porous polymer," Energy Sources, Part A Recover. Util. Environ. Eff., vol. 40, no. 8, pp. 929 939, 2018.

[29] H. Anh Tuan and C. Minh Quang, "A mini review of using oleophilic skimmers for oil spill recovery," J. Mech. Eng. Res. Dev., vol. 41, no. 2, pp. 92-96, 2018

[30] A. T. Hoang et al., "An absorption capacity investigation of new absorbent based on polyurethane foams and rice straw for oil spill cleanup," Pet. Sci. Technol., vol. 36, no. 5, pp. 361-370, 2018.

[31] V. V. Le, D. C. Nguyen, and A. T. Hoang, "The potential of using the renewable energy aiming at environmental protection," Int. J. Latest Eng. Res. Appl., vol. 2, no. 7, pp. 54-60, 2017.

[32] A. T. Hoang and M. T. Pham, "Influences of heating temperatures on physical properties, spray characteristics of bio-oils and fuel supply system of a conventional diesel engine," Int. J. Adv. Sci. Eng. Inf. Technol., vol. 8, no. 5, 2018.

[33] A. T. Hoang, "Prediction of the density and viscosity of biodiesel and the influence of biodiesel properties on a diesel engine fuel supply system," J. Mar. Eng. Technol., 2018. https://doi.org/10.1080/20464177.2018.1532734

[34] A. T. Hoang and A. T. Le, "A review on deposit formation in the injector of diesel engines running on biodiesel," Energy Sources, Part A Recover. Util. Environ. Eff., 2018 https://doi.org/10.1080/15567036.2018.1520342.

[35] A. T. Hoang, Q. V. Tran, and X. D. Pham, "Performance and Emission Characteristics of Popular 4-Stroke Motorcycle Engine in Vietnam Fuelled with Biogasoline Compared with Fossil Gasoline,' Int. J. Mech. Mechatronics Eng., vol. 18, no. 2, pp. 97-103, 2018.

[36] A. T. Hoang and V. V. Pham, "A study of emission characteristic, deposits, and lubrication oil degradation of a diesel engine running on preheated vegetable oil and diesel oil," Energy Sources, Part A Recover. Util. Environ. https://doi.org/10.1080/15567036.2018.1520344.

[37] A. T. Hoang and V. V. Pham, "Impact of Jatropha Oil on Engine Performance, Emission Characteristics, Deposit Formation, and Lubricating Oil Degradation," Combust. Sci. Technol., 2018. https://doi.org/10.1080/00102202.2018.1504292.

[38] M. T. Pham, A. T. Hoang, A. T. Le, A. R. M. S. Al-Tawaha, V. H Dong, and V. V. Le, "Measurement and prediction of the density and viscosity of biodiesel blends," Int. J. Technol., vol. 9, no. 5, pp. 10151026, 2018

[39] A. T. Hoang and D. N. Cao, "Some methods of reducing NOx components in exhaust gas," Int. J. Eng. Res. Manag. Stud., vol. 4, no. 5, pp. 11-18, 2017

[40] X. D. P. A.T. Hoang, M.M. Noor, "Comparative Analysis on Performance and Emission Characteristic of Diesel Engine Fueled with Heated Coconut Oil and Diesel Fuel," Int. J. Automot. Mech. Eng., vol. 15, no. 1, pp. 5110-5125, 2018.

[41] A. T. Hoang, "A Design and Fabrication of Heat Exchanger for Recovering Exhaust Gas Energy from Small Diesel Engine Fueled with Preheated Bio-oils," Int. J. Appl. Eng. Res., vol. 13, no. 7, pp. 5538-5545, 2018

[42] A. T. Hoang, "Waste heat recovery from diesel engines based on Organic Rankine Cycle,” Appl. Energy, vol. 231, pp. 138-166, 2018.

[43] A. T. Hoang and V. T. Nguyen, "Emission Characteristics of a Diese Engine Fuelled with Preheated Vegetable Oil and Biodiesel," Philipp. J. Sci., vol. 146, no. 4, pp. 475-482, 2017.

[44] T. A. Hoang and V. Van Le, "The Performance of A Diesel Engine Fueled With Diesel Oil, Biodiesel and Preheated Coconut Oil," Int. J. Renew. Energy Dev., vol. 6, no. 1, pp. 1-7, 2017.

[45] A. Weintrit and T. Neumann, Marine Navigation and Safety of Sea Transportation: STCW, Maritime Education and Training (MET), Human Resources and Crew Manning, Maritime Policy, Logistics and Economic Matters. CRC Press, 2013.

[46] F. Douvere, "The importance of marine spatial planning in advancing ecosystem-based sea use management," Mar. policy, vol. 32, no. 5 pp. 762-771, 2008. 